\title{
REGRESSION ANALYSIS TO DETERMINE STATURE FROM HAND ANTHROPOMETRY AMONG ILOCANO POPULATION IN PHILIPPINES FOR PERSON IDENTIFICATION
}

\author{
Nataraja Moothy $\mathrm{T}^{1 *}$, Ivan Nikkimor $\mathrm{LD}^{2}$, Ariel Pontillas ${ }^{3}$, Wirasuta IMAG ${ }^{4}$. \\ ${ }^{1}$ Corresponding author and Professor of Forensic Sciences, Faculty of Health and \\ Life Sciences, Management and Science University, Shah Alam, Post Code 40100, \\ Selangor, Malaysia. \\ ${ }^{2}$ Master student in Forensic Science, Management and Science University, Shah \\ Alam, Selangor, Malaysia \\ ${ }^{3}$ Field Supervisor and Police Superintendent, Misamis Oriental Mindanao, National \\ Philippine Police, Philippines. \\ ${ }^{4}$ UPT Lab Forensic Science and Criminology, Udayana University, Indonesia \\ *Email: natrajamoorthy @ rediffmal.com \& nataraajan64@msu.edu.my
}

\begin{abstract}
Stature determination aids the person identification during forensic investigation. The human hand research is the current topic of interest among forensic scientist, forensic medicine experts and anthropologists. Based on sample size analysis, the study involved consented 60 males and 60 females, age ranged from 18 to 55 years old. Stature and hand lengths measurements were made with Stadiometer and Vernier Calipers for analysis. From each participant, ten hand length measurements, five from left and five from right hands were taken. The five length measurements in left hand are the inter-distance between the distal traverse crease of the wrist (LH) and tip of thumb (T), index finger (I), middle finger (M), ring finger (R) \& little finger (L), as abbreviated LHT, LHI, LHM, LHR and LHL. Similarly, the right hand lengths indicated as RHT, RHI, RHM, RHR, and RHL. The data were statistically analyzed by using SPSS software, version 23 and column chart. The information about age, gender, name, and place of origin of the participants was coded for easy reference. This study finally developed regression equations to determine stature from hand anthropometry among Ilocano population in Philippines for person identification
\end{abstract}

Keywords: Forensic Science, Stature, Hand Anthropometry, Ilocanos, Philippines

\section{INTRODUCTION}

Human hand research is a hot topic among forensic scientists, forensic medicine experts and anthropologists [1]. Fatality identification is a pivotal problem in forensic investigation [2]. Stature prediction from highly decomposing bodies and dismembered body parts is one of the biggest issues during forensic investigation [3],[4].
Stature, age, sex, and ancestry helps in narrowing down the pool of the possible victims and provide useful clues in person identification [5], [6], [7].

Wildlife forensic experts are also working for identification of animals [8] through physical evidence left by the animals such as impressions, hair, tissue and blood 
stain etc. [9]. Researchers have established the existence of relationship between stature and human body parts like hand, finger, foot, trunk, and bones, hence the stature can be predicted from hand anthropometry [10]. Globally researchers are showing interest in stature determination from hand [3] and handprint [11] anthropometry based on populations and ethnics in forensic perspective. Literature review shows the non-availability of standards relating stature and hand anthropometry among Ilocano population in Philippines. Hence, this investigation developed population specific regression formulae to determine stature from hand anthropometry of the study population for forensic application.

\section{RESEARCH METHODS Materials and Methods}

Based on sample size calculation, the study recruited 60 males and 60 females of adult Ilocanos, an indigenous ethnic group living in Philippines. These subjects have consented their participation in this study and MSU ethical committee had approved this research to proceed. The age range of the participant is from 18 to 55 years since stature at 18 years, accepted as adult in human beings [10]. The stature of the participants was measured with a portable Statiometer and hand lengths with Vernier calipers and recorded the data. From each hand, measured five hand length measurements with a total of 10-hand length per subject, along with stature and recorded the data.

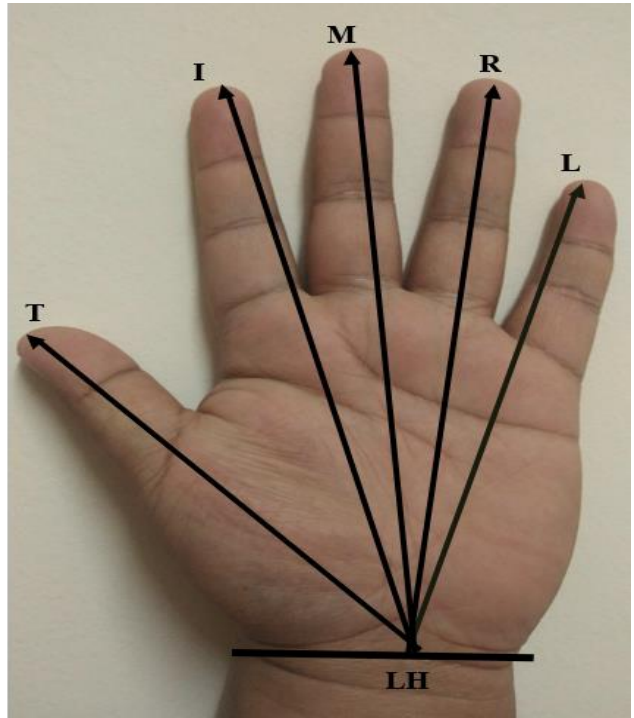

Figure 1. Landmarks and various hand length measurements

The five length measurements in the left hand are the inter-distance between the distal traverse crease of the left wrist (LH) and tip of 1 . Thumb (T), 2. Index finger (I), 3. Middle finger (M), 4. Ring finger (R) and 5. Little finger (L), abbreviated as LHT, LHI, LHM, LHR and LH (Fig 1). Similarly, the right hand lengths, abbreviated as RHT, RHI, RHM, RHR, and RHL. The data were statistically analyzed by using SPSS software, version 23 and developed regression formulae for stature prediction. Bar graphs pictorially presented the gender and hand length variations and presented the results in tables. The participants' information, such as age, gender, name, and place of origin, as coded with sample ID for anonymity. 


\section{RESULTS and DISCUSSION Results}

Table 1 presents the stature and related information such as sample size $(\mathrm{N})$, minimum (min) and maximum (max) stature of the subjects and standard deviation (SD).

Table 1. Stature of known and unknown gender among Ilacano population in Philippines.

\begin{tabular}{cccccc}
\hline Variable & N & Min & Max & Mean & SD \\
\hline Male & 60 & 126 & 151 & 140.57 & 6.21 \\
Female & 60 & 114 & 135 & 124.75 & 5.12 \\
Unknown & 120 & 114 & 151 & 132.66 & 9.76 \\
gender & & & & & \\
\hline N- Sample & size; & Min - Minimum; & Max- \\
Maximum; SD-Standard deviation &
\end{tabular}

The result in Table 1 shows that the stature of male ranged from 126 $\mathrm{cm}$ to $151 \mathrm{~cm}$ with a mean value of $140.57 \mathrm{~cm}$ while female stature ranged from $114 \mathrm{~cm}$ to $135 \mathrm{~cm}$ (mean 124.75 $\mathrm{cm}$ ). The mean value for unknown gender (pooled male and female sample) is $132.66 \mathrm{~cm}$. Pooled sample is the combination of male and female subject became unknown gender, as found in real crime scenarios.

Figure 2 shows the male-female stature variation among the study population.

Figure 2. Bar graph showing the gender variation in stature

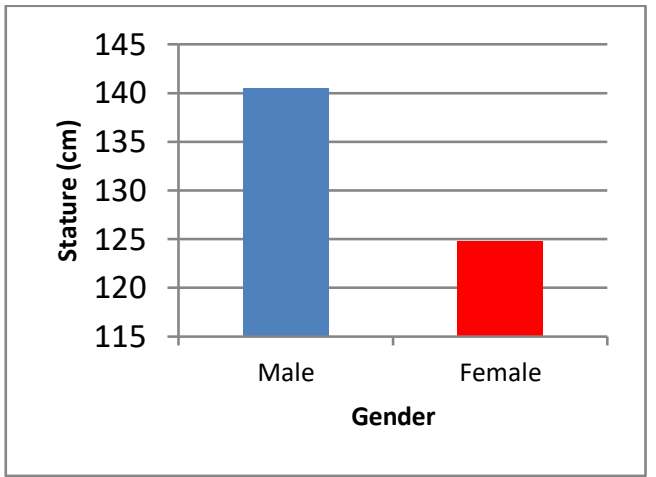

Tables 2-4 present the right and left hand lengths among male, female and unknown gender of Ilocanos in Philippines.

Table 2. Hand lengths (in $\mathrm{cm}$ ) among male Ilacano population in Philippines $(\mathrm{N}=60)$

\begin{tabular}{ccccc}
\hline Length & Min & Max & Mean & SD \\
\hline LHT & 11.88 & 14.67 & 13.11 & 0.69 \\
LHI & 16.16 & 19.98 & 17.80 & 0.84 \\
LHM & 16.95 & 20.73 & 18.54 & 0.83 \\
LHR & 15.92 & 19.97 & 17.37 & 0.87 \\
LHL & 13.26 & 17.06 & 15.02 & 0.76 \\
RHT & 12.22 & 14.61 & 13.24 & 0.61 \\
RHI & 16.50 & 19.97 & 17.73 & 0.68 \\
RHM & 17.02 & 20.20 & 18.40 & 0.71 \\
RHR & 16.09 & 19.54 & 17.45 & 0.74 \\
RHL & 13.68 & 17.25 & 15.05 & 0.68 \\
\hline
\end{tabular}

Ten hand length measurements taken with ten fingers from each subject. Table 2 shows the various hand lengths of male Ilacanos and the mean middle hand length $(18.54 \mathrm{~cm})$ is the longest while thumb hand length $(13.11 \mathrm{~cm})$ is the shortest in both hands of male. 
Table 3. Hand lengths (in $\mathrm{cm}$ ) among female Ilocano population in Philippines ( $\mathrm{N}=60)$

\begin{tabular}{ccccc}
\hline Length & Min & Max & Mean & SD \\
\hline LHT & 11.07 & 13.39 & 11.94 & 0.45 \\
LHI & 15.33 & 17.83 & 16.25 & 0.54 \\
LHM & 15.79 & 18.80 & 16.95 & 0.62 \\
LHR & 14.61 & 17.68 & 15.95 & 0.55 \\
LHL & 12.68 & 15.39 & 13.74 & 0.49 \\
RHT & 11.02 & 13.07 & 11.90 & 0.46 \\
RHI & 14.93 & 17.46 & 16.14 & 0.59 \\
RHM & 15.56 & 18.19 & 16.87 & 0.63 \\
RHR & 14.64 & 17.27 & 15.96 & 0.57 \\
RHL & 12.98 & 15.31 & 13.70 & 0.51 \\
\hline
\end{tabular}

Table 4. Hand lengths (in $\mathrm{cm}$ ) among unknown Ilocano population in Philippines $(\mathrm{N}=60)$

\begin{tabular}{ccccc}
\hline Length & Min & Max & Mean & SD \\
\hline LHT & 11.07 & 14.67 & 12.52 & 0.83 \\
LHI & 15.33 & 19.98 & 17.03 & 1.05 \\
LHM & 15.79 & 20.73 & 17.75 & 1.08 \\
LHR & 14.61 & 19.97 & 16.66 & 1.02 \\
LHL & 12.68 & 17.06 & 14.38 & 0.90 \\
RHT & 11.02 & 14.61 & 12.57 & 0.86 \\
RHI & 14.93 & 19.97 & 16.93 & 1.02 \\
RHM & 15.56 & 20.20 & 17.63 & 1.02 \\
RHR & 14.64 & 19.54 & 16.71 & 0.99 \\
RHL & 12.98 & 17.25 & 14.38 & 0.91 \\
\hline
\end{tabular}

Table 5. Linear regression formulae to determine stature from combined left and right hand lengths among male Ilocano population in Philippines $(\mathrm{N}=60)$

$\mathrm{p}$ value $<0.001$

\begin{tabular}{ccccc}
\hline $\begin{array}{c}\text { Regression } \\
\text { formulae }\end{array}$ & $\mathrm{R}$ & $\mathrm{R}^{2}$ & $\begin{array}{c}\text { Adjusted } \\
\mathrm{R}^{2}\end{array}$ & $\mathrm{SEE}$ \\
\hline $\mathrm{S}=48.124$ & 0.69 & 0.48 & 0.469 & \pm 4.53 \\
$+7.016 \mathrm{HT}$ & & & & \\
$\mathrm{S}=42.364$ & 0.67 & 0.44 & 0.433 & \pm 4.68 \\
$+5.529 \mathrm{HI}$ & & & & \\
$\mathrm{S}=31.183$ & 0.71 & 0.50 & 0.489 & \pm 4.44 \\
$+5.922 \mathrm{HM}$ & & & & \\
$\mathrm{S}=51.486$ & 0.64 & 0.40 & 0.393 & \pm 4.84 \\
$+5.116 \mathrm{HR}$ & & & & \\
$\mathrm{S}=58.743$ & 0.61 & 0.37 & 0.36 & \pm 4.97 \\
$+5.442 \mathrm{HL}$ & & & & \\
\hline
\end{tabular}

Table 6. Linear regression formulae to determine stature from combined left and right hand lengths among female Ilocano population in Philippines $(\mathrm{N}=60)$

$\mathrm{p}$ value $<0.00$

\begin{tabular}{ccccc}
\hline $\begin{array}{c}\text { Regression } \\
\text { formulae }\end{array}$ & $\mathrm{R}$ & $\mathrm{R}^{2}$ & $\begin{array}{c}\text { Adjusted } \\
\mathrm{R}^{2}\end{array}$ & $\mathrm{SEE}$ \\
\hline $\mathrm{S}=52.293$ & 0.51 & 0.26 & 0.243 & \pm 4.46 \\
$+6.078 \mathrm{HT}$ & & & & \\
$\mathrm{S}=44.944$ & & 0.28 & 0.263 & \pm 4.40 \\
$+4.927 \mathrm{HI}$ & 0.53 & 0.28 & & \\
$\mathrm{~S}=50.637$ & & & & \\
$+4.383 \mathrm{HM}$ & 0.52 & 0.27 & 0.261 & \pm 4.40 \\
$\mathrm{~S}=50.836$ & & & & \\
$+4.633 \mathrm{HR}$ & 0.49 & 0.24 & 0.226 & \pm 4.51 \\
$\mathrm{~S}=43.710$ & & & & \\
$+5.907 \mathrm{HL}$ & 0.55 & 0.30 & 0.285 & \pm 4.33 \\
\hline
\end{tabular}

Table 7. Linear regression formulae to determine stature from combined left and right hand lengths among unknown gender Ilocano population in Philippines ( $\mathrm{N}=60)$

\begin{tabular}{lcccc}
\hline $\begin{array}{l}\text { Regression } \\
\text { formulae }\end{array}$ & $\mathrm{R}$ & $\mathrm{R}^{2}$ & $\begin{array}{c}\text { Adjusted } \\
\mathrm{R}^{2}\end{array}$ & $\mathrm{SEE}$ \\
\hline $\mathrm{S}=$ & & & & \\
$\begin{array}{l}10.186 \mathrm{HT}+ \\
4.845\end{array}$ & 0.86 & 0.73 & 0.731 & \pm 5.06 \\
$\mathrm{~S}=8.162 \mathrm{HI}$ & 0.85 & 0.73 & 0.726 & \pm 5.11 \\
-5.935 & & & & \\
$\mathrm{~S}=$ & & & & \\
$8.071 \mathrm{HM}-$ & 0.86 & 0.73 & 0.731 & \pm 5.06 \\
$\begin{array}{l}10.125 \\
\mathrm{~S}=\end{array}$ & & & & \\
$\begin{array}{l}8.199 \mathrm{HR}- \\
4.117\end{array}$ & 0.83 & 0.69 & 0.685 & \pm 5.48 \\
$\mathrm{~S}=$ & & & & \\
$9.158 \mathrm{HL}+$ & 0.83 & 0.69 & 0.690 & \pm 5.43 \\
0.982 & & & & \\
\hline & & & $\mathrm{p}$ value $<0.001$
\end{tabular}

The table 3 presents the various hand length measurements in female Ilocanos. Here again the middle hand length is longer than other four hand lengths in both sides. The mean hand lengths of both male and female 
subjects as illustrated in the form of bar graphs (Fig 3 and Fig 4). The mean left hand length and right hand are not similar, thus reflected the bilateral asymmetry.

Figure 3. Bar graph showing various hand length measurements among male Ilocanos in Philippines.

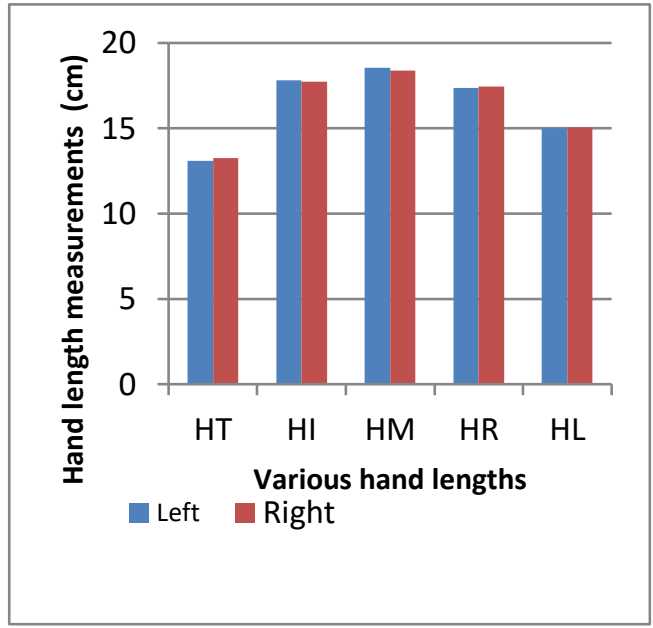

Figure 4. Bar graph showing various hand length measurements among female Ilocanos in Philippines.

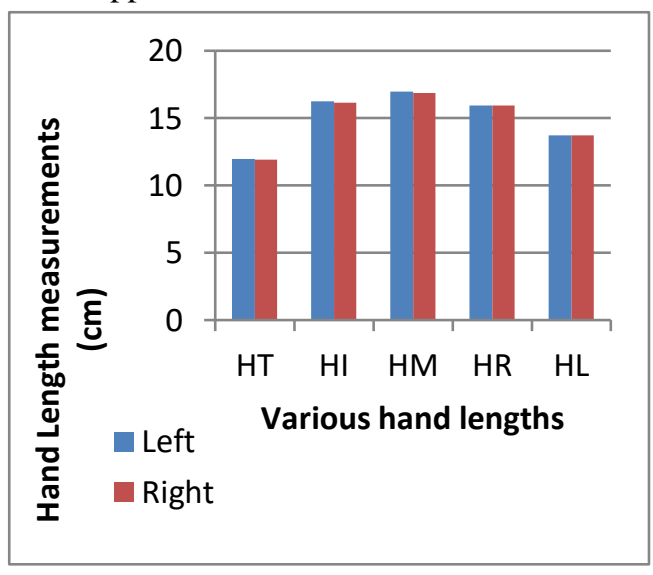

The male hand lengths are longer than female hand lengths, showing the general male and female difference. The bilateral hand lengths of male and female as presented in figure 5. The left hand length and right hand length show bilateral asymmetry but not significant in this population.

Figure 5. Bar graph showing bilateral hand length measurements among Ilocanos in Philippines

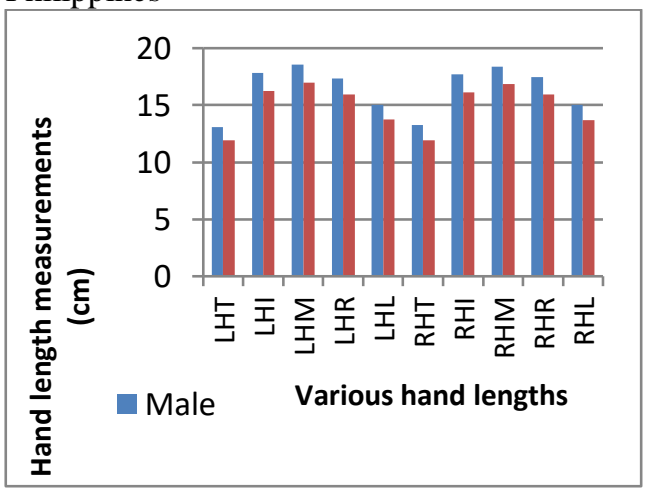

The result of unknown gender (Table 4) shows that the middle hand length is the longest in both sides but not similar. The standard deviation (SD) in unknown gender is slightly higher than male and females. Because of the non-existence of significant bilateral asymmetry among left and right hand lengths of this population, the study combined the left and right hand lengths, as unified and developed regression equations to determine stature for forensic application, irrespective of left or right hands found in crime scene.

Tables 5-7 show the linear regression formulae to determine stature (S) from various hand lengths among males, females and unknown gender. The correlation coefficient (R) values are statistically significant and higher correlation exists in unknown gender (0.804-0.847) than males 
(0.545-0.676) and females (0.4470.529). The coefficient of determination $\left(\mathrm{R}^{2}\right)$, the predictive accuracy, is found to be higher in unknown gender and statistically significant $(<0.001)$.

\section{Discussion}

The Ilocanos, also called as Ilokanos, or Iloko ethnic is the third largest group in Philippines, mostly residing within Ilocos region in the northwestern seaboard of Luzon, Philippines. Ilocanos, known for their hardworking, appreciative, simple and determined lifestyle. Most of them speak Ilocano, which is part of the northern Philippines subgroup of Austronesian family language. As a second language, they also speak Tagalog and English, most Ilocanos are Roman Catholics [12]. The age range of the study population is $18-55$, considered adult since it was shown that people attained adult at 18 years old [13]. The result of the study showed that the mean stature of male is $140.57 \mathrm{~cm}$ while female is 124.75 $\mathrm{cm}$. On the contrary, the stature of Thailand population (male: $171.50 \mathrm{~cm}$ and female $159.63 \mathrm{~cm}$ ) and middle hand lengths (Male R:18.18 cm, L :18.13; Female R:14.90, L: 14.80) are different from Ilocano population [14]. Similarly, in Sri Lankan population study of stature determination, the stature of male is $170.14 \mathrm{~cm}$ with hand length, $19.01 \mathrm{~cm}$ and female stature is $157.55 \mathrm{~cm}$ with hand length, $17.62 \mathrm{~cm}$ [15]. Researchers have conducted autopsybased study on stature estimation from hand lengths, involving dead bodies, received for autopsy examination against living persons in India. The mean stature of the male deceased was $163.54 \mathrm{~cm}$ with mean hand length of $18.60 \mathrm{~cm}$ while female deceased stature was $155.69 \mathrm{~cm}$ with mean hand length of $16.39 \mathrm{~cm}$. The study revealed that the male right hand is larger than left hand whereas in females left hand is slightly larger than right. For stature estimation from hand lengths, many researchers have used only one hand length, the longest hand length, i.e. hand length with middle finger [10], [14], [16], [17].

However, the present study used five-hand length measurements from left and five from right side for stature determination. The incidents of mass disaster, industrial accidents, and major bomb blasting are frequent and the dismembered human body parts in the crime scenes are the primary challenge to the investigators for person identity. The present study developed five linear regression formulae separately for male, female and unknown gender. A total of 15 equations were developed so that the presence of partial dismember hand parts with unknown gender become a valuable clue for stature determination, leading to person identification. It is cumbersome to face this challenge if only one regression equation developed for stature determination for a population. Another advantage of this research is the development of regression equations to determine stature from pooled sample or unknown gender. In real crime scenarios, in many incidences, it is difficult to find out the 
gender of the dismembered and decomposed hands and hence the unknown gender equations developed in this study would find use to determine stature of the dismembered hand parts to solve the mystery.

\section{CONCLUSION}

The study concluded with the development of fifteen population specific regression formulae to determine stature from hand anthropometry among Ilocanos in Philippines. The study result would be useful even in the presence of partial or portion of hand pieces found in the crime scenes. Researchers are encouraged to develop standards for stature determination on various populations for crime scene application.

\section{ACKNOWLEDGEMENT}

The authors are thankful to Ilocono participants for their full cooperation throughout the research. We are grateful to National Philippine Police for the acceptance as field supervisor and successful completion of this collaborative work. Thanks are due to RMC, Management and Science University for their encouragement in research and publications.

\section{REFERENCES}

[1] Ivan Nikkimor LD, Nataraja Moorthy T. Estimation of stature from hand anthropometry among Kagay-Anon population in Philippines. Int $\mathbf{J}$ Med Tox Leg Med. 2018; 23 (3): 1-3.
[2] Ozaslan A, Iscan MY, Ozlan I, Tugey H, Koc S. Estimation of stature from body parts. Forensic Sci Int. 2013; 132 (1): 40-45.

[3] Amitava P, Sujaya D, Piyal M, Prakash CS. Estimation of stature from hand dimensions in Bengalee population, West Bengal, India. Egypt J Forensic Sci.2016;6:90-98.

[4] Hairunnisa MAK, Nataraja Moorthy. Stature estimation from foot outline measurements in adult Bidayuhs of east Malaysia by regression analysis. Indonesian J Legal Forensic Sci. 2013; 3(1): 6-10.

[5] Natarajamoorthy T, Ahmad MM, Boominathan R, Raman $\mathrm{N}$, Stature estimation from footprint measurements in Indian Tamils by regression analysis. Egypt J Forensic Sci. 2014; 4: 7-16.

[6] Nataraja Moorthy T, Hairunnisa MAK. Estimation of stature from footprint anthropometry using regression analysis: a study on the Bidayuh population of east Malaysia. Arab J Forensic Sci Forensic Med. 2015; 1(1): 13-21.

[7] Nataraja Moorthy T, Hairunnisa MAK. Sex determination from footprint ridge density in Bidayuh population in Malaysian Borneo. International J Med Tox Legal Med. 2018;21(3):158-161.

[8] Nishant K, Vrijesh KY, Ajay KR. Wildlife Forensic: Current techniques and their limitations. 
J Forensic Sci Crim. 2017;5(4):1-6.

[9] Linacre A, Shanam ST. An overview to the investigative approach to species testing in wildlife forensic science. Inves Genet. 2011;2(2):1-9.

[10] Rajesh G, Thakur PS, Dudu SK, Rastogi AK. Estimation of stature from anthropometry of hand: An interesting autopsy based study in Madya Pradesh, India. Int $\mathrm{J}$ Res Med Sci. 2016;4(6):1873-78.

[11] Ivan Nikkimor LD, Nataraja Moorthy T, Pravina D, Ariel Philip IP. Regression analysis to determine stature from handprint anthropometry among Visayans, an indigenous ethnic group in Philippines for crime scene application. Int J Med Tox Legal Med. 2019; 22, (3\&4): 6973.

[12] Severino GA, Marife DA. Cultrul practices of the tribal communites in the province of Ilocos Sur, Philippines. Asia Paci J Adv Busi Soc Stud. 2017;3(1):250-260.

[13] Nataraja Moorthy T, Khairulmazida M, Mohamad HY, Jayaprakash PT. Estimation of stature based on foot length of Malays in Malaysia. Australian J Forensic Sci. 2011;43(1):13-26.

[14] Laulathaphol P, Tiensuwan M, Riengrojpitak S. Estimation of stature from hand measurements in Thais. SDU Res J. 2013;6(1):37-47.

[15] Ilayperuma I, Nanayakara G, Palahepitivia N. Prediction of personal stature based on hand length. Galle Med J. 2009;14(1):15-16.

[16] Pal A, De S, Sengupta P, Maity $P$, Dhara PC. Estimation of stature from hand dimensions in Bengali population, West Bengal, India. Egypt J. Forensic Sci. 2016;6:90-98.

[17] Mahrous AI, Athar MK, Hassan $\mathrm{AH}$, Hany GI, Ameer MH. Estimation of stature from hand dimensions in North Saudi population. Saudi J Forensic Med Sci. 2018;1(1): 19-27.

[18] Ibegbu AO, David ET, Umana UE, Musa SA. Association of hand with height in Nigerian schoolchildren. J Biol Life Sci. 2013; 4(2):83-94. 